\title{
Genotype frequency distributions of 28 SNP markers in two commercial lines and five Chinese native chicken populations
}

\author{
Jing-Jing Li' ${ }^{1}$ Long Zhang ${ }^{2}$, Peng Ren ${ }^{1}$, Ye Wang ${ }^{1}$, Ling-Qian Yin ${ }^{1}$, Jin-Shan Ran ${ }^{1}$, Xian-Xian Zhang ${ }^{1}$ and
} Yi-Ping Liu ${ }^{1 *}$ (D)

\begin{abstract}
Background: Modern breeding in the poultry industry mainly aims to produce high-performance poultry lines and breeds in two main directions of productivity, meat and eggs. To understand more about the productive potential of lowly selected Chinese native chicken populations, we selected 14 representative SNP markers strongly associated with growth traits or carcass traits and 14 SNP markers strongly associated with egg laying traits through previous reports. By using the MassArray technology, we detected the genotype frequency distributions of these 28 SNP markers in seven populations including four lowly selected as well as one moderately selected Sichuan native chicken populations, one commercial broiler line and one commercial layer line.

Results: Based on the genotype frequency distributions of these 28 SNP markers in 5 native chicken populations and 2 commercial lines, the results suggested that these Chinese indigenous chicken populations have a relatively close relationship with the commercial broiler line but a marked distinction from the commercial layer line. Two native chicken breeds, Shimian Caoke Chicken and Daheng Broilers, share similar genetic structure with the broiler line.

Conclusions: Our observations may help us to better select and breed superior domestic chickens and provide new clues for further study of breeding programs in local chicken populations.
\end{abstract}

Keywords: Genetic marker, Growth trait, Egg laying trait, Native chicken

\section{Background}

The improvement of growth traits and egg laying traits is of major importance in modern poultry industry to enable producers to meet the increasing demands for meat and eggs [1]. Defining the molecular genetic basis of these economically important traits is a major task in chicken breeding research [2]. Heritability estimates showed that chicken growth traits and egg laying traits could be enhanced by genetic improvement [3, 4]. Most economically important traits are controlled by a series of genes or quantitTative trait loci (QTLs) [2]. Following the rapid advancement of molecular genetic technologies and the availability of data, multiple researches have

\footnotetext{
*Correspondence: liuyp578@163.com

${ }^{1}$ Farm Animal Genetic Resources Exploration and Innovation Key Laboratory of Sichuan Province, Sichuan Agricultural University, Chengdu 611130, Sichuan, China

Full list of author information is available at the end of the article
}

been performed to identify, map and analyze QTLs for application in marker-assisted selection (MAS) programs in chickens [5-8]. At present, there are two main strategies applied for detecting QTLs: association analysis using candidate genes and genome wide association study (GWAS) [9].

Chinese indigenous chickens possess a series of desirable meat qualities including greater tenderness and preferred flavors that are often favored by consumers [10, 11]. Besides, they are relatively disease-resistant and well-adapted to the harsh environments [12, 13]. However, unlike commercial chicken breeds that have undergone numerous generations of intense artificial selection, native chicken breeds have a relatively slow growth rate and low egg production [14]. Therefore, faster genetic improvement for higher growth or carcass traits and egg laying performances in Chinese native chicken breeds is 
expected to be achieved by breeding program [15]. Single nucleotide polymorphism (SNP) is a kind of efficient genetic marker based upon the variability at the nucleotide level [16]. Understanding the genotype frequency distributions of these SNPs that have significant associations with productive traits in Chinese native chicken populations will greatly uncover the productive potential for meat or egg propose of these birds.

To characterize the genetic variations and genetic relationships among different populations using DNA markers, a total of 28 identified SNP markers, including 14 growth or carcass traits associated loci and 14 egg laying related genome positions, were selected from the previous reports [17-33]. By using the MassArray technology, an Agena Bioscience MassARRAY System which is capable of efficiently genotyping tens to hundreds of SNPs with high accuracy, we detected the genotype frequency distributions of the $28 \mathrm{SNP}$ markers in seven populations including four lowly selected as well as one moderately selected Sichuan native chicken populations, one commercial broiler line and one commercial layer line $[34,35]$. The findings of the present study may lead to a better understanding of the relationship between native and commercial populations and will be helpful in the selection of superior native chickens.

\section{Results}

Genotype frequencies of the 28 SNP markers in the seven populations

Comparisons of genotype frequency distributions of the 28 SNPs markers in the seven chicken populations are shown in Fig. 1 and Mass spectrometry for 28 SNP markers are in Additional file 1: Figure S1 and Additional file 2: Figure S2. We did not detect the variation at NC_006092.4: g.25657391 T > A and no significant difference was found between the native chicken populations and the commercial broiler line at rs13687128 and rs14202565 $(P>0.05)$ (Fig. 1a). There were $5,5,6,4,3$ SNP markers presenting significant difference $(P<0.05)$ between $\mathrm{CK}$ and $\mathrm{CB}$, JYB and CB, GYG and CB, GSH and $\mathrm{CB}, \mathrm{DHB}$ and $\mathrm{CB}$, respectively (Fig. 1a). However, genotype frequencies of the broiler and layer populations appeared greatest difference in the 14 markers related to growth or carcass traits, with 4 SNP markers showing significant difference $(P<0.05)$ and 6 SNP markers showing extremely significant difference $(P<0.01)$ (Fig. 1a). Interestingly, the frequencies of the genotypes at most of the SNP markers associated with egg production traits exhibit extremely significant difference $(P<$ 0.01 ) between LLH and the other six chicken populations. The frequencies of genotype GG, CC, AA, AA at rs14491030, rs16349546, rs14581563, rs315420959 in LLH reached $100 \%$, with great genetic diversity in other Chinese indigenous chicken populations at these four
SNP makers. These four specific genotypes may be advantageous for better egg performances in LLH due to intensive selection to achieve higher egg productivity.

\section{Clustering of the seven chicken populations}

Consistent population structure with Bayesian cluster analysis among samples based on genotype frequencies of all 28 SNP markers was detected by STRUCTURE outputs. Results of the STRUCTURE analysis are given in Fig. 2 and plots for delta- $K$ suggested that $K=3$ was the optimum number of clusters among the full datasets (Fig. 2a) since the value of delta $\mathrm{K}$ was the highest when $\mathrm{K}$ was 3 . Thus, we only displayed the population structure with 3 clusters here (Fig. 2). With this setting, commercial layer LLH formed a distinct cluster, which is consistent with the results of genotype frequencies. Besides, CK and DHB have similar population structure with $\mathrm{CB}$. Other native chicken populations, including JYB, GYG, GSH, have share a similar population structure, which is distinctively different from both commercial broiler and layer.

\section{Discussion}

Chicken growth and egg production traits are two economically important traits, which are determined by genetic, nutritional and environmental factors [18]. The genetic makeup ultimately has a fundamental influence and uncovering the molecular mechanism results in more efficient selections for meat or egg production in chicken populations [16]. To date, a large number of experiments have been performed successfully to identify QTLs for economically important traits in chickens [36]. After numerous generations of intense artificial selections, the frequencies of QTL alleles on these economyrelated traits have increased in commercial lines [37]. However, no studies have been conducted to detect the genotype frequency of different native populations on these QTLs. In the present study, we investigated genetic diversities and relationships between and within seven chicken populations including two commercial breeds and five native breeds based on genotyping individuals at 28 SNP sites. Among the nearest genes or candidate genes correlated with growth traits, OCA2 and SLC27A1 genes take part in transmembrane transport process, while IGFBP2 and MC4R genes are involved in insulin secretion pathway. Besides, ATGL and SLC27A1 genes are capable of regulating lipid homeostasis including triglyceride catabolic or biosynthetic process. The other genes such as IGFBP2, OCA2, CAPN3, SETDB2 genes, play roles in cell growth, cell proliferation, cell activation and satellite cell activation, respectively (Additional file 3 : Table S1). As for the potential candidate genes for egg production traits, BMP15, GREM1, GREM2 genes are important for the regulation of bone morphogenetic 


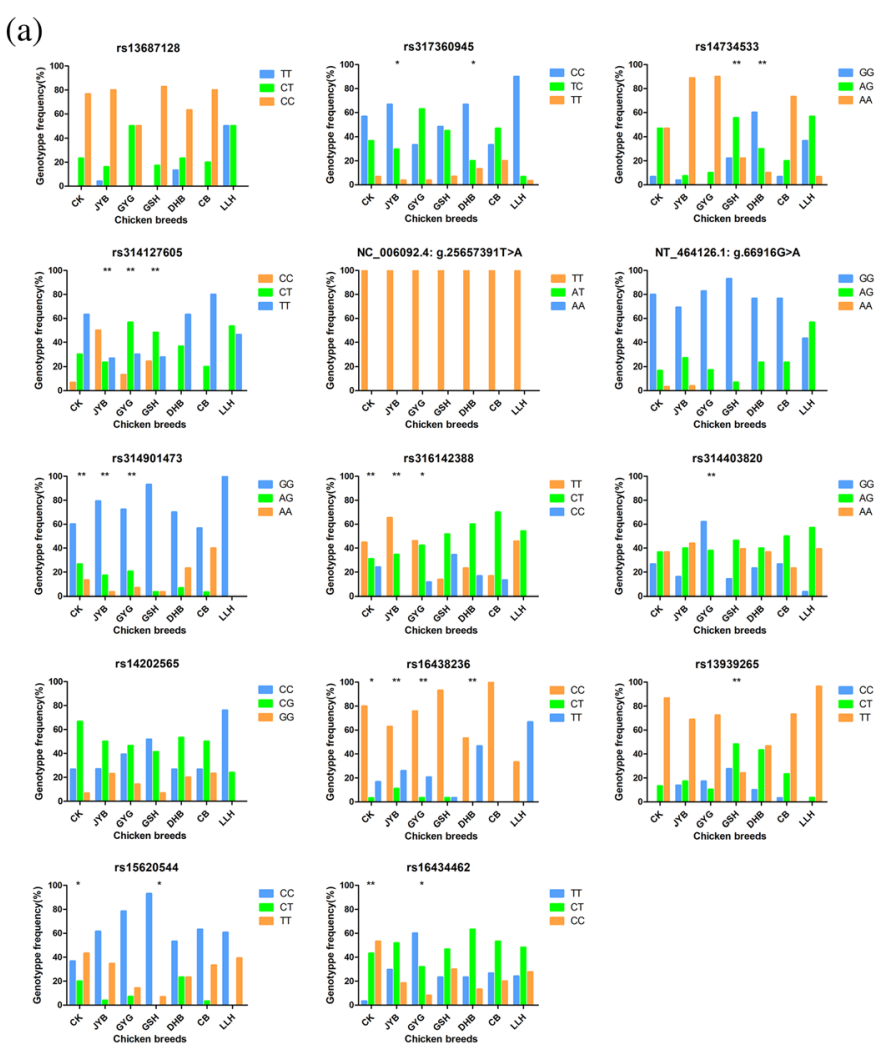

(b)
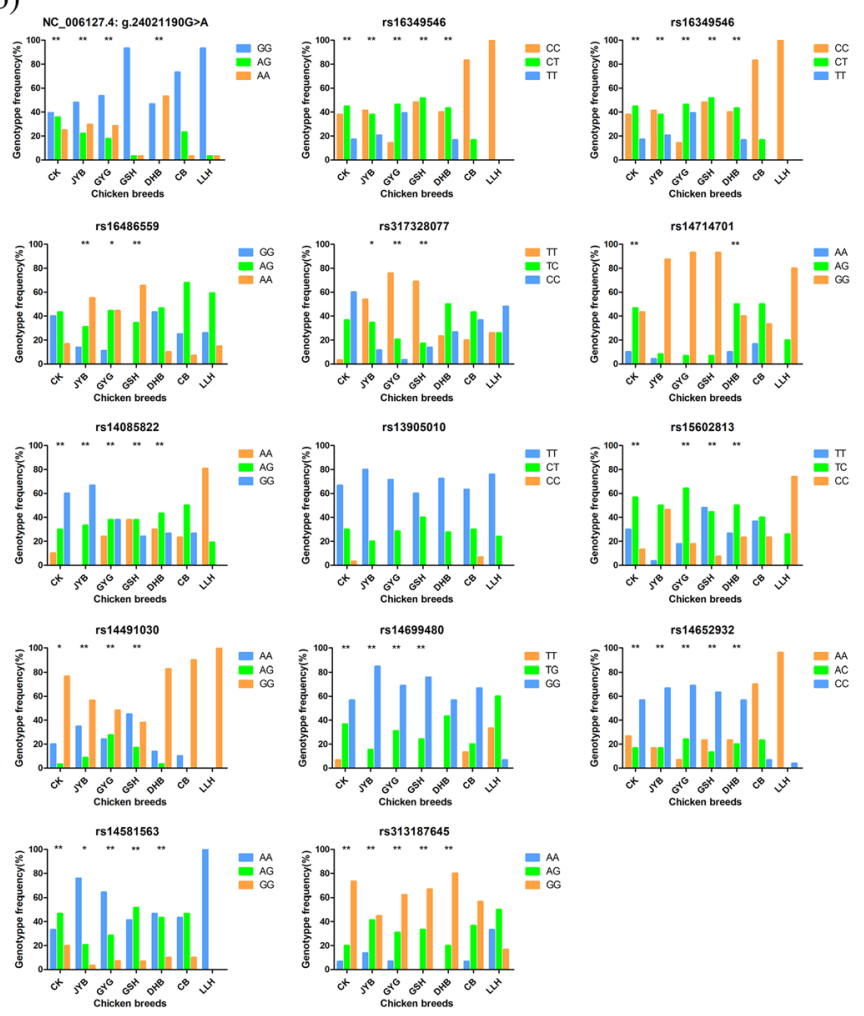

Fig. 1 (See legend on next page.) 
(See figure on previous page.)

Fig. 1 Comparisons of genotype frequency distributions on 28 SNP markers. a Genotype frequency distributions of 14 SNP markers associated with growth traits or carcass traits on seven populations. * on the top of each native chicken population represented significant difference between native chicken population and $\mathrm{CB}(P<0.05)$; ${ }^{* *}$ represented extremely significant difference between native chicken population and $\mathrm{CB}$ $(P<0.01)$. $\mathbf{b}$ Genotype frequency distributions of 14 SNP markers associated with egg production traits on seven populations. ${ }^{*}$ on the top of each native chicken population represented significant difference between native chicken population and $\mathrm{LLH}(P<0.05) ;{ }^{* *}$ represented extremely significant difference between native chicken population and LLH $(P<0.01)$

proteins (BMPs) signaling pathway. HMGCR and SEL1L gene take part in the pathways of lipid metabolic process. Besides, CBFB, NCAPG, LCORL and GTF2A1 genes are key regulators of transcription by RNA polymerase II. The consequence types of all SNP markers include missense variants, synonymous variants, intron variants, 3 prime UTR variants and intergenic variants (Additional file 4: Table S2).

Compared with the previous studies, our results further provided a verification of these genetic makers. For example, Nie et al., showed that rs13687128 is significantly associated with BW at 21, 35 days, SD at 63 days $(P<0.05)$ and highly significantly associated with $\mathrm{BW}$ at 28 days and ADG from 0 to 4 weeks of age $(P<0.01)$, and the $\mathrm{C}$ allele is advantageous for chicken growth traits (Table 1) [25]. While our findings suggested that there is no significant difference in the genotype frequency contribution between $\mathrm{CB}$ and native chicken breeds and the $\mathrm{C}$ allele is the dominating allele in commercial broiler line and native chicken breeds but completely absent in LLH (Fig. 1a). Similarly, Fig. 1a showed that the allele $\mathrm{A}$ and $\mathrm{C}$ were both absent in LLH at rs314901473 and rs316142388, respectively, while individuals with these two alleles were reported to have better growth performance at early growth stage in F2 resource population made up of the reciprocal cross between Gushi chicken and Anka broilers and at late growth stage in Jinghai yellow chickens, respectively (Table 1) [17, 22]. Although the frequency of allele A in $\mathrm{CB}$ was the highest among all seven chicken populations, the genotype GG was still the primary genotype in all chicken populations at rs314901473. Besides, Fig. 1a showed that the frequency of allele $C$ at rs16438236 in CB reached $100 \%$ while the allele $\mathrm{C}$ was the minor allele in LLH population, which is consistent with previous finding that the allele $\mathrm{C}$ is the favorable allele for growth traits in a F2 resource population from the reciprocal crosses of Silky Fowl and White Plymouth Rock [31]. The frequency of the favorable allele $G$ for carcass traits at 49 days at rs314403820 was higher than that of allele $\mathrm{A}$ in CB and GYG populations, whereas the allele A occurred more often than the allele $\mathrm{G}$ in the other chicken populations [18]. However, Nie et al., reported that individuals with the CT genotype at rs314127605 have the

(a)

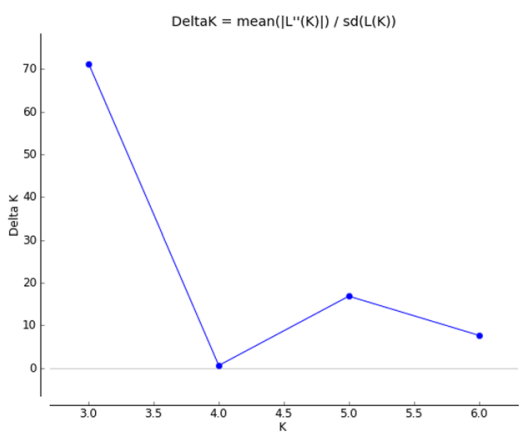

(b)

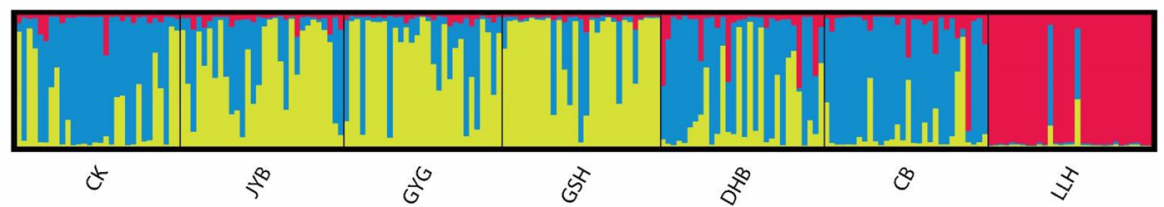

Fig. 2 a Plots for detecting the number of $\mathrm{K}$ groups that best fit the data. The best value of $\mathrm{K}$ was 3 since Delta $\mathrm{K}$ was highest when $\mathrm{K}=3$. b Population structure based on the genetic variation of 28 SNP markers inferred by Bayesian clustering. Each individual was shown as a thin vertical line partitioned into 3 colored components representing inferred membership in 3 genetic clusters 
Table 1 Summary of 14 SNP markers associated with growth traits or carcass traits

\begin{tabular}{|c|c|c|c|c|c|c|c|c|}
\hline SNP marker & $\mathrm{GGA}^{\mathrm{a}}$ & Position $^{\mathrm{b}}$ & $\begin{array}{l}\text { Nearest } \\
\text { gene }^{c}\end{array}$ & $\begin{array}{l}\text { consequence } \\
\text { type }^{d}\end{array}$ & SNP & Traits $^{e}$ & Chicken populations ${ }^{f}$ & Reference \\
\hline rs13687128 & 1 & $\begin{array}{l}92,866 \\
047\end{array}$ & POU1F1 & $\begin{array}{l}\text { synonymous } \\
\text { variant }\end{array}$ & $\mathrm{T} / \mathrm{C}$ & $\begin{array}{l}\text { BW at } 21,35 \text { days and SD at } \\
63 \text { days }(P<0.05), B W \text { at } 28 \\
\text { days and ADG from } 0 \text { to } 4 \\
\text { weeks of age }(P<0.01)\end{array}$ & $\begin{array}{l}\text { F2 resource population made up of } \\
\text { reciprocal cross between White } \\
\text { Recessive Rock and Xinghua chickens }\end{array}$ & [25] \\
\hline rs317360945 & 7 & $\begin{array}{l}23,386 \\
524\end{array}$ & IGFBP2 & $\begin{array}{l}\text { synonymous } \\
\text { variant }\end{array}$ & $C / T$ & $\begin{array}{l}\text { BW at } 7,14,21,28,35,42,49, \\
56,90 \text { days, and } C W, E W \\
\text { BMW at } 90 \text { days }(P<0.01) \\
\text { LMW at } 90 \text { days }(P<0.05)\end{array}$ & $\begin{array}{l}\text { F2 resource population made up of } \\
\text { reciprocal cross between White } \\
\text { Recessive Rock and Xinghua chickens }\end{array}$ & [23] \\
\hline rs14734533 & 4 & $\begin{array}{l}70,143 \\
452\end{array}$ & TBC1D1 & $\begin{array}{l}3 \text { prime UTR } \\
\text { variant }\end{array}$ & $\mathrm{G} / \mathrm{A}$ & $\begin{array}{l}\text { BW, CW, EW, SEW and LMW } \\
\text { at } 90 \text { days }(P<0.05)\end{array}$ & Erlang Mountainous chickens & [28] \\
\hline rs314127605 & 5 & $\begin{array}{l}15,760 \\
767\end{array}$ & ATGL & $\begin{array}{l}\text { missense } \\
\text { variant }\end{array}$ & $C / T$ & $\begin{array}{l}\text { BW at } 14,21,35,63,70,77 \\
\text { days, } C F W \text { and AFW }(P< \\
0.05), B W \text { at } 42,49 \text {, and } 56 \\
\text { days }(P<0.01)\end{array}$ & $\begin{array}{l}\text { F2 resource population made up of } \\
\text { reciprocal cross between White } \\
\text { Recessive Rock and Chinese Xinghua } \\
\text { chickens }\end{array}$ & [26] \\
\hline $\begin{array}{l}\text { NC_ } \\
006092.4: \\
\text { g.25657391 } \\
\text { T>A }\end{array}$ & 5 & $\begin{array}{l}25,657 \\
391\end{array}$ & CAPN3 & intron variant & T/A & $\begin{array}{l}\text { BW, EP, BMP at } 90 \text { days }(P< \\
0.05)\end{array}$ & $\begin{array}{l}\text { five commercial pure lines (S01, S02, S03, } \\
\text { S05, and D99) and } 4 \text { Chinese native } \\
\text { breeds (Huiyang Huxu chicken, } \\
\text { Qingyuan Ma chicken, Caoke chicken } \\
\text { and Mountainous black-bone chicken) }\end{array}$ & [33] \\
\hline $\begin{array}{l}\text { NT_ } \\
\text { 464126.1: g. } \\
66916 \mathrm{G}>\mathrm{A}\end{array}$ & 30 & 66,916 & SLC27A1 & $\begin{array}{l}\text { missense } \\
\text { variant }\end{array}$ & $\mathrm{G} / \mathrm{A}$ & $\begin{array}{l}\text { LW, CW, SEW, EW and BMWP } \\
\text { at } 91 \text { days }(P<0.05)\end{array}$ & $\begin{array}{l}\text { eight meat-type quality chicken popula- } \\
\text { tions including S01, S02, S03, S05, S06, } \\
\text { D } 99 \text {, S05 × S01, and S06 × S01 of Dahen } \\
\text { chicken }\end{array}$ & [29] \\
\hline rs314901473 & 1 & $\begin{array}{l}14,235 \\
966\end{array}$ & PBEF1 & $\begin{array}{l}\text { synonymous } \\
\text { variant }\end{array}$ & $\mathrm{G} / \mathrm{A}$ & $\begin{array}{l}\text { BW at } 4,6 \text { weeks, and } S L \text {, } \\
\text { BWLR and BFD at } 4 \text { weeks } \\
(P<0.05) \text {, and BBL at } 4 \text { weeks } \\
(P<0.01)\end{array}$ & $\begin{array}{l}\text { F2 resource population made up of } \\
\text { reciprocal cross between Gushi chicken } \\
\text { and Anka broilers }\end{array}$ & [22] \\
\hline rs316142388 & 1 & $\begin{array}{l}169,208 \\
798\end{array}$ & SETDB2 & intron variant & $\mathrm{T} / \mathrm{C}$ & $\begin{array}{l}\text { BW at } 12,14,16 \text { weeks }(P< \\
0.05)\end{array}$ & Jinghai yellow chickens & [17] \\
\hline rs314403820 & 3 & $\begin{array}{l}67,466 \\
233\end{array}$ & $\mathrm{FOXO3}$ & intron variant & $\mathrm{G} / \mathrm{A}$ & $\begin{array}{l}\text { CW, SEW, EW and BMW at } 49 \\
\text { days }(P<0.05)\end{array}$ & $\begin{array}{l}\text { White Recessive Rock and Xinghua } \\
\text { chickens }\end{array}$ & [18] \\
\hline rs14202565 & 2 & $\begin{array}{l}69,322 \\
385\end{array}$ & MC4R & $\begin{array}{l}\text { missense } \\
\text { variant }\end{array}$ & $\mathrm{G} / \mathrm{C}$ & $\begin{array}{l}\text { BW, CW, SHL at } 7 \text { weeks }(P< \\
0.05)\end{array}$ & $\begin{array}{l}\text { F6 generation of Arbor Acres grandsire } \\
\text { line }\end{array}$ & [24] \\
\hline rs16438236 & 4 & $\begin{array}{l}77,857 \\
657\end{array}$ & $\begin{array}{l}87 \mathrm{~kb} U \\
\text { BOD1L }\end{array}$ & $\begin{array}{l}\text { intergenic } \\
\text { variant }\end{array}$ & $C / T$ & $\begin{array}{l}\text { BW at } 10,11,12 \text { weeks and } \\
\text { ADG from } 6 \text { weeks to } 12 \\
\text { weeks of age }(P<0.01)\end{array}$ & $\begin{array}{l}\text { F2 resource population made up of } \\
\text { reciprocal crosses of Silky Fowl and } \\
\text { White Plymouth Rock }\end{array}$ & [31] \\
\hline rs13939265 & 1 & $\begin{array}{l}130,801 \\
788\end{array}$ & OCA2 & intron variant & $C / T$ & $\begin{array}{l}\text { BW at } 11 \text { weeks and } 12 \text { weeks } \\
(P<0.01)\end{array}$ & $\begin{array}{l}\text { F2 resource population made up of } \\
\text { reciprocal crosses of Silky Fowl and } \\
\text { White Plymouth Rock }\end{array}$ & [31] \\
\hline rs15620544 & 4 & $\begin{array}{l}77,233 \\
676\end{array}$ & FBXL5 & intron variant & $C / T$ & BW at 10 weeks $(P<0.01)$ & $\begin{array}{l}\text { F2 resource population made up of } \\
\text { reciprocal crosses of Silky Fowl and } \\
\text { White Plymouth Rock }\end{array}$ & [31] \\
\hline rs16434462 & 4 & $\begin{array}{l}73,027 \\
691\end{array}$ & $-^{h}$ & $\begin{array}{l}\text { intergenic } \\
\text { variant }\end{array}$ & $\mathrm{T} / \mathrm{C}$ & $\begin{array}{l}\text { BW at } 11,12 \text { weeks and ADG } \\
\text { from } 6 \text { weeks to } 12 \text { weeks of } \\
\text { age }(P<0.01)\end{array}$ & $\begin{array}{l}\text { F2 resource population made up of } \\
\text { reciprocal crosses of Silky Fowl and } \\
\text { White Plymouth Rock }\end{array}$ & [31] \\
\hline
\end{tabular}

${ }^{a}$ 'GGA' refers to chromosome of Gallus gallus

${ }^{\mathrm{b}}$ Position was based on chicken genome version of Gallus_gallus-5.0

'The nearest genes were obtained from the NCBI database or the reference in the rightmost column

${ }^{d}$ The consequence types and SNP were obtained from Ensemble database or the reference in the rightmost column

'The traits were obtained from the reference in the rightmost column and showed strong association with SNP marker in the leftmost column

${ }^{\mathrm{f}}$ The chicken populations refer to the experimental material of the reference

${ }^{\prime}$ ' $U$ ' indicates that the SNP is upstream of the gene

h, _' indicates that there was no nearest gene of rs 16434462

highest value for BW at $14,21,35,42,49,56,63,70,77$ days in a F2 resource population made up of reciprocal cross between White Recessive Rock and Chinese Xinghua chickens (Table 1) [26]. In our study, the frequency of $\mathrm{CT}$ in the $\mathrm{CB}$ population was lower than that of $\mathrm{CT}$ in the other populations, and the TT genotype was the primary genotype $(80 \%)$ in the commercial broiler line (Fig. 1a). The same condition appeared in the results of SNP markers associated with egg production traits in Fig. 1b. Han et al., showed that the egg number in 
chickens with the allele A is significantly higher than the individuals with the allele $\mathrm{G}$ at NC_006127.4: g24021190 G > A in F5 generation of Qing-Jiao-Ma breeding chickens $(P<0.01)$ (Table 2$)$ [20] while the GG genotype (93.33\%) occurred much more frequently than the other genotypes in our commercial layer line. Besides, Tyasi et al., showed that genotype GG and TC at rs16486559 and rs317328077 are both favorable for egg production at 56, 66 weeks in Chinese Dagu chicken breed (Table 2) while our results implied that the genotype AG and CC were found at a higher frequency in LLH at rs16486559 and rs317328077, respectively(Fig. 1b) [27]. These results collectively demonstrated that the identification of QTLs is probably populationspecific and the conflicting observations may be caused by genetic background differentiation, geographic distances or the limited sample size of experimental populations [38].

As is shown in Fig. 2, the STRUCTURE analysis exhibited a distinct clustering of LLH population, which suggested that more work is still needed for the genetic improvement of Sichuan native chicken breeds for egg purpose based on the SNP markers we selected here. Furthermore, CK, DHB and CB populations appeared to be grouped separately, suggesting that these three chicken breeds share closer genetic relationship based on these genotype frequencies of the 28 SNP markers. In fact, CK and DHB present more appropriate for meat propose than the other three native chicken breeds according to their productive performance (Table 3). DHB

Table 2 Summary of 14 SNP markers associated with reproduction traits

\begin{tabular}{|c|c|c|c|c|c|c|c|c|}
\hline SNP marker & GGA & Position & $\begin{array}{l}\text { Nearest } \\
\text { gene }\end{array}$ & $\begin{array}{l}\text { consequence } \\
\text { type }\end{array}$ & SNP & Traits & Chicken populations & Reference \\
\hline $\begin{array}{l}\mathrm{NC}_{-} \\
006127.4: \\
\mathrm{g} 24021190 \\
\mathrm{G}>\mathrm{A}\end{array}$ & Z & $\begin{array}{l}24,021 \\
190\end{array}$ & HMGCR & intron variant & $\mathrm{G} / \mathrm{A}$ & EN at 300 days $(P<0.01)$ & $\begin{array}{l}\text { F5 generation of Qing-Jiao-Ma } \\
\text { breeding chickens }\end{array}$ & {$[20]$} \\
\hline rs16349546 & 4 & $\begin{array}{l}1,874 \\
976\end{array}$ & BMP15 & $\begin{array}{l}\text { synonymous } \\
\text { variant }\end{array}$ & $\mathrm{C} / \mathrm{T}$ & $\begin{array}{l}\text { AFE, EWFE, EW at } 43 \text { weeks, EP } \\
\text { at } 43 \text { weeks, EP at } 46 \text { weeks and } \\
\text { EP at } 48 \text { weeks }(P<0.05)\end{array}$ & LaiWu Black chickens & {$[21]$} \\
\hline $\begin{array}{l}\mathrm{NC}_{-} \\
006096.4: \\
\mathrm{g} 22545152 \\
\mathrm{G}>\mathrm{C}\end{array}$ & 9 & $\begin{array}{l}22,545 \\
152\end{array}$ & RARRES1 & $\begin{array}{l}\text { nonsynonymous } \\
\text { variant }\end{array}$ & $\mathrm{G} / \mathrm{C}$ & $\begin{array}{l}\text { EPR from } 169 \text { day to } 280 \text { day of } \\
\text { age }(P<0.01)\end{array}$ & $\begin{array}{l}\text { F2 resource population crossed by } \\
\text { White Leghorn males and Rhode } \\
\text { Island Red females }\end{array}$ & {$[9]$} \\
\hline rs16486559 & 5 & $\begin{array}{l}30,579 \\
826\end{array}$ & GREM1 & $\begin{array}{l}\text { synonymous } \\
\text { variant }\end{array}$ & $\mathrm{G} / \mathrm{A}$ & EP at $43,57,66$ weeks $(P<0.05)$ & Chinese Dagu chickens & {$[27]$} \\
\hline rs317328077 & 3 & $\begin{array}{l}36,305 \\
243\end{array}$ & GREM2 & $\begin{array}{l}\text { synonymous } \\
\text { variant }\end{array}$ & $\mathrm{T} / \mathrm{C}$ & EP at $30,57,66$ weeks $(P<0.05)$ & Chinese Dagu chickens & {$[27]$} \\
\hline rs14714701 & 7 & $\begin{array}{l}20,960 \\
237\end{array}$ & $\mathrm{KCNH7}$ & $\begin{array}{l}\text { intergenic } \\
\text { variant }\end{array}$ & $A / G$ & FEW $(P<0.01)$ & Jinghai Yellow Chicken & {$[19]$} \\
\hline rs14085822 & 3 & $\begin{array}{l}12,329 \\
322\end{array}$ & CDC42BPA & intron variant & $A / G$ & EW at 300 days $(P<0.01)$ & Jinghai Yellow Chicken & {$[19]$} \\
\hline rs13905010 & 1 & $\begin{array}{l}92,440 \\
932\end{array}$ & GJA5 & intron variant & $\mathrm{T} / \mathrm{C}$ & $\begin{array}{l}\text { EN between the age of } 300 \\
\text { and } 462 \text { days }(P<0.01)\end{array}$ & Jinghai Yellow Chicken & [19] \\
\hline rs15602813 & 11 & $\begin{array}{l}2,417 \\
179\end{array}$ & CBFB & intron variant & $\mathrm{T} / \mathrm{C}$ & $\begin{array}{l}\text { EN between the age of } 300 \\
\text { and } 462 \text { days }(P<0.01)\end{array}$ & Jinghai Yellow Chicken & {$[19]$} \\
\hline rs14491030 & 4 & $\begin{array}{l}76,458 \\
342\end{array}$ & NCAPG & missense variant & $A / G$ & $\begin{array}{l}\text { EN between the age of } 26 \text { and } \\
28 \text { weeks }(P<0.01) \text {, EN between } \\
\text { the age of } 42 \text { and } 46 \text { weeks } \\
(P<0.01)\end{array}$ & $\begin{array}{l}\text { six generations of a purebred } \\
\text { brown egg layer line }\end{array}$ & {$[30]$} \\
\hline rs14699480 & 4 & $\begin{array}{l}76,411 \\
761\end{array}$ & LCORL & intron variant & $\mathrm{T} / \mathrm{G}$ & $\begin{array}{l}\text { EN between the age of } 26 \text { and } \\
28 \text { weeks }(P<0.01)\end{array}$ & $\begin{array}{l}\text { six generations of a purebred } \\
\text { brown egg layer line }\end{array}$ & {$[30]$} \\
\hline rs14652932 & 8 & $\begin{array}{l}23,991 \\
868\end{array}$ & FAF1 & intron variant & $\mathrm{A} / \mathrm{C}$ & $\begin{array}{l}\text { EN between the age of } 26 \text { and } \\
28 \text { weeks }(P<0.01)\end{array}$ & $\begin{array}{l}\text { six generations of a purebred } \\
\text { brown egg layer line }\end{array}$ & {$[30]$} \\
\hline rs315420959 & 5 & $\begin{array}{l}41,036 \\
029\end{array}$ & $\begin{array}{l}21 \mathrm{~kb} U \\
\text { SEL1L }\end{array}$ & $\begin{array}{l}\text { intergenic } \\
\text { variant }\end{array}$ & $\mathrm{A} / \mathrm{G}$ & $\begin{array}{l}\text { EN between the age of } 21 \text { and } \\
40 \text { weeks }(P<0.01)\end{array}$ & $\begin{array}{l}\text { F2 resource population made up of } \\
\text { reciprocal crosses between White } \\
\text { Leghorn and Dongxiang Blue- } \\
\text { shelled chicken }\end{array}$ & {$[32]$} \\
\hline rs313187645 & 5 & $\begin{array}{l}40,875 \\
680\end{array}$ & GTF2A1 & intron variant & $\mathrm{G} / \mathrm{A}$ & $\begin{array}{l}\text { EN between } 21 \text { and } 40 \text { weeks } \\
\text { of age }(P<0.01)\end{array}$ & $\begin{array}{l}\text { F2 resource population made up of } \\
\text { reciprocal crosses between White } \\
\text { Leghorn and Dongxiang Blue- } \\
\text { shelled chicken }\end{array}$ & {$[32]$} \\
\hline
\end{tabular}


Table 3 Morphological description of Chinese native chicken populations

\begin{tabular}{|c|c|c|c|c|c|}
\hline $\begin{array}{l}\text { Chicken } \\
\text { breeds }\end{array}$ & Source & $\begin{array}{l}\text { BW at } 90 \text { days of } \\
\text { age }(\mathrm{kg})^{\mathrm{a}}\end{array}$ & $\begin{array}{l}\text { BW at } 120 \text { days of } \\
\text { age }(\mathrm{kg})\end{array}$ & $\begin{array}{l}\text { BW at } 150 \text { days of } \\
\text { age }(\mathrm{kg})\end{array}$ & $\begin{array}{l}\text { EN at } 300 \text { days } \\
\text { of age }\end{array}$ \\
\hline JYB & $\begin{array}{l}\text { Wanyuan Hengkang Agricultural Development } \\
\text { Company }\end{array}$ & $1.29 \pm 0.15$ & $1.37 \pm 0.15$ & $1.50 \pm 0.06$ & 95 \\
\hline GYG & $\begin{array}{l}\text { Sichuan Tianguan Ecological Agriculture and Animal } \\
\text { Husbandry Company }\end{array}$ & $0.93 \pm 0.06$ & $1.41 \pm 0.09$ & $1.58 \pm 0.14$ & 90 \\
\hline CK & Shimian Pengcheng Breeding Company & $2.30 \pm 0.24$ & $2.89 \pm 0.06$ & $3.89 \pm 0.15$ & 120 \\
\hline GSH & Sichuan Agricultural University Breeding Farm & $0.89 \pm 0.01$ & $1.28 \pm 0.02$ & $1.48 \pm 0.05$ & 115 \\
\hline $\mathrm{DHB}$ & Sichuan Daheng Poultry Breeding Company & $1.85 \pm 0.03$ & $2.52 \pm 0.02$ & $3.11 \pm 0.07$ & 90 \\
\hline
\end{tabular}

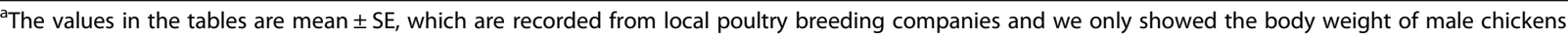

is a moderately selected chicken breed for meat production in China and the selective breeding for this breed seems to have already achieved a great genetic improvement based on our results. Other native chicken populations, including JYB, GYG, GSH, share a similar population structure in STRUCTURE analysis, which is distinctively different from both of the commercial broiler and layer line. This is consistent with the fact that these native chicken populations have been under low selection and breeding. A great diversity was also observed between commercial chicken populations and native populations in the previous reports. Using 29 autosomal microsatellite markers, Mtileni et al. demonstrated that all the domestic chickens were diverse from the commercial lines and the village chicken formed a single cluster while commercial populations formed separate and distinct clusters [39]. Besides, in a study that employed 30 microsatellite markers, 15 chicken population samples collected from Kenya, Uganda, Ethiopia and Sudan were used to detect genetic diversity and the results showed a closely genetic relationship among these indigenous chickens but a marked distinction from commercial breeds [40].

Chinese chicken breeds exhibit a wide spectrum of phenotypic and morphologic properties, harboring valuable genetic resource of functional mutations affecting a wide range of properties [41]. On the basis of maintaining the uniqueness of these breeds, the rich genetic diversity requires effective characterization for breeding and conservation purposes [42]. The success of these strategies is closely hinged on a good knowledge of the phenotypic and genetic architecture of indigenous chicken populations. Applying these molecular genetic markers into lowly selected Chinese native chicken breeds with MAS will greatly enhance the intensity of selection and efficiently accelerate great genetic improvement for growth and egg production traits. At the same time, it will bring great convenience to animal breeding work, such as guiding the rapid screening of breeding materials, designing molecular combination schemes for target traits, and evaluating the molecular progress of breeding programs.
In summary, our observations provided new clues to understand the productive potential of Chinese native chicken and may benefit the further study of economically important traits and breeding programs in Chinese local chicken populations.

\section{Conclusions}

Based on the genotype frequency distributions of 28 SNP markers, the great diversity is observed between commercial chicken populations and native populations. Besides, five Chinese indigenous chicken populations have a relatively close relationship with the commercial broiler line but a marked distinction from the commercial layer line. Two native chicken breeds, CK and DHB, share similar genetic structure with the commercial broiler line.

\section{Methods}

\section{Selection and summary of 28 SNP markers}

Based on multiple previous reports [17-33], we have chosen 14 characteristic SNP markers strongly associated with growth traits or carcass traits $(P<0.05)$ including rs13687128, rs317360945, rs14734533, rs314127605, NC_ 006092.4: g.25657391 T > A, NT_464126.1: g.66916G > A, rs314901473, rs316142388, rs314403820, rs14202565, rs16438236, rs13939265, rs15620544, rs16434462 and 14 characteristic SNP markers with strongly association with egg production traits $(P<0.05)$ including NC_006127.4: g.24021190G > A, rs16349546, NC_006096.4: g22545152 G > C, rs16486559, rs317328077, rs14714701, rs14085822, rs13905010, rs15602813, rs14491030, rs14699480, rs14652932, rs315420959 and rs313187645 for genotype frequency analysis. The specific information of the SNP markers is given together with their genetic background and corresponding traits in Tables 1 and 2. These SNP markers are all identified by candidate gene method and GWAS from previous reports and the information including positions, nearest genes, consequence types of these SNP markers were obtained from the National Center for Biotechnology Information (NCBI) database (https://www. ncbi.nlm.nih.gov/) or Ensemble database (http://www. ensembl.org). The growth traits mainly included body 
weight (BW) and average daily weight gains (ADG) at different stages, while the carcass traits mainly included carcass weight $(\mathrm{CW})$, eviscerated weight $(\mathrm{EW})$, eviscerated percentage (EP), semi-eviscerated weight (SEW), slanting length (SL), shank diameters (SD), shank length (SHL), chest width (CHW), cingulated fat width (CFW), abdominal fat pad weight (AFW), breast muscle weight (BMW), leg muscle weight (LMW), breast muscle percentage (BMP), breast muscle water loss rate (BWLR), breast bone length (BBL) and breast muscle fiber density (BFD). The laying traits mainly included egg number (EN), egg production rate (EPR), first egg weight (FEW), age at first egg (AFE), egg production (EP) and egg weight (EW) at different age. The gene ontology (Go) annotations of the nearest genes associated with growth traits (Additional file 3: Table S1.) were summarized from the GeneCards database (https://www.genecards.org/) and the Uniprot database (https://www.uniprot.org/), while these related with egg laying traits are in Additional file 4: Table S2.

\section{Sampling and genomic DNA extraction}

A total of 210 samples from seven chicken breeds were used to screen the allelic variation of the selected loci. The chicken breeds are Caoke Chicken (CK), Guanyuan Grey Chicken (GYG), Jiuyuan Black Chicken (JYB), Green Shell Hen (GSH), Daheng Broiler (DHB), Cobb Broiler (CB) and Lohman Laying Hen (LLH) (Table 4). Each population was composed of 30 unrelated individuals, which were gifted with permissions from local poultry breeding companies. The morphological description of CK, GYG, JYB, GSH and DHB were collected from local poultry breeding companies (Table 3). The samples of each breed line were selected from one site only. Venous blood samples were collected from 210 samples under the wing of the chickens for genomic DNA extraction. Total genomic DNA was isolated with the TIANamp Blood DNA Kit in accordance with the manufacturer's instructions, and then stored at $-20^{\circ} \mathrm{C}$, prepared for PCR amplification. Birds were released after blood extraction and the entire study was approved by the Committee on the Care and Use of Laboratory Animals of the State-level Animal Experimental Teaching
Demonstration Center of Sichuan Agricultural University [43].

\section{Polymerase chain reaction (PCR) and genotyping}

PCR primers of all 28 SNP markers were designed with Assay Desigh 3.1 software and synthesized by Beijing Huada gene laboratory. PCR was carried out in a final volume of $5 \mu \mathrm{L}$ containing $1 \mu \mathrm{L}(20 \mathrm{ng} / \mu \mathrm{L})$ of DNA template and $4 \mu \mathrm{L}$ PCR master mix (Additional file 5: Table S3). The PCR amplifcation conditions were as, initial denaturation at $94^{\circ} \mathrm{C}$ for $5 \mathrm{~min}$, followed by 45 cycles of $94{ }^{\circ} \mathrm{C}$ for 20 s, $56^{\circ} \mathrm{C}$ for 30 s, and primer extension at $72{ }^{\circ} \mathrm{C}$ for $180 \mathrm{~s}$. The PCR products were disposed with shrimp alkaline phosphatase (SAP) to remove remaining deoxyribonucleotide triphosphate (dNTP) (Additional file 6: Table S4). A total volume of $7 \mu \mathrm{L}$ containing $5 \mu \mathrm{L}$ products and $2 \mu \mathrm{L}$ SAP mix were put in PCR device with the amplifcation condition of $37^{\circ} \mathrm{C}$ for 20 $\min , 85^{\circ} \mathrm{C}$ for $5 \mathrm{~min}$. After the sufficient dispose of SAP, EXTEND mix was compounded for single base extension (Additional file 7: Table S5). A total volume of $9 \mu \mathrm{L}$ containing $2 \mu \mathrm{L}$ EXTEND mix and $7 \mu \mathrm{L} \mathrm{SAP+PCR} \mathrm{reac-}$ tion products was into extension condition of $94^{\circ} \mathrm{C}$ for $30 \mathrm{~s}, 94^{\circ} \mathrm{C}$ for $5 \mathrm{~s}$, followed by 45 cycles of $94^{\circ} \mathrm{C}$ for $5 \mathrm{~s}$, $52^{\circ} \mathrm{C}$ for $5 \mathrm{~s}, 80^{\circ} \mathrm{C}$ for $5 \mathrm{~s}$, and a final extension at $72{ }^{\circ} \mathrm{C}$ for $180 \mathrm{~s}$. Finally, the PCR products were spotted into SpectroCHIP bioarray with the automatic instrument. MALDI-TOF-MS (SpectroREADER, Sequenom) was used to detect the chips. The plate data and scatter plot of data were processed by TYPER4.0 software.

\section{Statistical analysis}

The genotype frequencies of the 28 SNP markers in seven chicken breeds were calculated by direct counting method [40]. The histograms of genotypic frequencies were made by Graphpad Prism 7, as we previously described [44, 45]. Comparisons of genotype frequencies between the Sichuan native chicken population and commercial broiler line or layer line were analyzed by Fisher's exact test in R software v3.5.3. Clustering of individuals based on the genotype of 28 SNP markers was performed by STRUCTURE v2.3.4, which can assess the

Table 4 The characterization of 7 chicken populations in this study

\begin{tabular}{llll}
\hline Populations & Abbreviation & Population size & Type \\
\hline Jiuyuan Black Chicken & JYB & 30 & Sichuan native breed (lowly selected) \\
Guanyuan Grey Chicken & GYG & 30 & Sichuan native breed (lowly selected) \\
Shimian Caoke Chicken & CK & 30 & Sichuan native breed (lowly selected) \\
Green Shell Hens & GSH & 30 & Sichuan native breed (lowly selected) \\
Daheng Broilers & DHB & 30 & Sichuan native breed (moderately selected for meat purpose) \\
Cobb Boilers & CB & 30 & Commercial boiler line (highly selected for meat purpose) \\
Lohman Laying Hens & LLH & 30 & Commercial layer line (highly selected for egg purpose) \\
\hline
\end{tabular}


likelihood values of partitioning their data into different numbers of clusters (K). A Monte Carlo Markov chain was run for $K=2$ to $K=8$ with a run length of burin period of 200,000 and a number of MCMC reps after burin of 1200,000. For each K-value, 10 repeated runs were performed to calculate the mean L (K) [46]. The results generated by the program STRUCTURE were compressed and uploaded to a web-based program named STRUCTURE HARVESTER (http://taylor0.biology.ucla.edu/structureHarvester/), which is used to detect the best number of clusters by Evanno method and generated indfiles and popfiles for use with CLUMPP [47, 48]. CLUMPP aligned cluster assignment across replicate analyses and the results were visualized using DISTRUCT [49].

\section{Supplementary information}

Supplementary information accompanies this paper at https://doi.org/10. 1186/s12863-020-0815-z.

Additional file 1: Figure S1. Mass spectrometry for 14 SNP markers associated with growth traits or carcass traits.

Additional file 2: Figure S2. Mass spectrometry for 14 SNP markers associated with egg production traits.

Additional file 3: Table S1. Go annotation of nearest genes associated with growth traits or carcass traits.

Additional file 4: Table S2. Go annotation of nearest genes associated with reproduction traits.

Additional file 5: Table S3. The composition of PCR master mix.

Additional file $\mathbf{6}$ Table S4. The composition of SAP mix.

Additional file 7: Table S5. The composition of Extend mix.

\section{Abbreviations}

ADG: Average daily weight gains; AFE: Age at first egg; AFW: Abdominal fat pad weight; ATGL: Adipose triglyceride lipase; BBL: Breast bone length; BFD: Breast muscle fiber density; BMP: Breast muscle percentage: BMP15: Bone morphogenetic protein 15; BMW: Breast muscle weight; BOD1L: Biorientation of chromosomes in cell division 1 like 1; BW: Body weight; BWLR: Breast muscle water loss rate; CAPN3: Calpain-3; CB: Cobb Broiler; CBFB: Core-binding factor beta subunit; CDC42BPA: CDC42 binding protein kinase alpha; CFW: Cingulated fat width; CHW: Chest width; CK: Caoke Chicken; CW: Carcass weight; DHB: Daheng Broiler; dNTP: deoxyribonucleotide triphosphate; EN: Egg number; EP: Egg production; EP: Eviscerated percentage; EPR: Egg production rate; EW: Egg weight; EW: Eviscerated weight; FAF1: Fas associated factor 1; FBXL5: F-Box And Leucine Rich Repeat Protein 5; FEW: First egg weight; FOXO3: Forkhead box O3; GJA5: Gap junction alpha-5; Go: Gene ontology; GREM1: Gremlin-1; GREM2: Gremlin-2; GSH: Green Shell Hen; GTF2A1: General transcription facter IIA subunit 1 variant 1; GWAS: Genome wide association study; GYG: Guanyuan Grey Chicken; HMGCR: 3-hydroxy-3-methylglutaryl coenzyme A reductase; IGFBP2: Insulin-like growth factor-binding protein 2; JYB: Jiuyuan Black Chicken; KCNH7: Potassium voltage-gated channel subfamily H member 7; LCORL: Ligand dependent nuclear receptor corepressor-like protein; LLH: Lohman Laying Hen; LMW: Leg muscle weight; MAS: Marker-assisted selection; MC4R: Melanocortin 4 receptor; NCAPG: Non-SMC condensin I complex subunit G; OCA2: Oculocutaneous albinism II; OCX-32: Ovocalyxin32; PBEF1: Nicotinamide phosphoribosyltransferase; PCR: Polymerase chain reaction; POU1F1: POU class 1 homeobox 1; QTL: Quantitative trait loci; SAP: Shrimp alkaline phosphatase; SD: Shank diameters; SEL1L: ERAD E3 ligase adaptor subunit; SETDB2: SET domain bifurcated 2; SEW: Semieviscerated weight; SHL: Shank length; SL: Slanting length; SLC27A1: Solute carrier family 27 member 1; SNP: Single nucleotide polymorphism; TBC1D1: TBC1 domain family member 1

\section{Acknowledgements}

Not applicable.

\section{Authors' contributions}

$J J L, L Z, P R, Y W$ and YPL designed the experiments and reviewed drafts of the paper. JJL, LQY and JSR performed the experiments and analyzed the data. JJL, XXZ collected the samples. All authors reviewed and approved the manuscript.

\section{Funding}

Sichuan Science and Technology Program, the Open Fund of Farm Animal Genetic Resources Exploration (Grant NO. 2016NYZ0043) offered assistance for investigation of the study, resources and collection. Innovation Key Laboratory of Sichuan Province (Grant NO. 2017JZ0033) was participated in the interpretation of data and writing the manuscript.

\section{Availability of data and materials}

All data generated or analyzed during this study are included in this published article.

\section{Ethics approval}

The Committee on the Care and Use of Laboratory Animals of the State-level Animal Experimental Teaching Demonstration Center of Sichuan Agricultural University has approved the experiments.

\section{Consent for publication}

Not applicable.

\section{Competing interests}

The authors declare that they have no competing interests.

\section{Author details}

${ }^{1}$ Farm Animal Genetic Resources Exploration and Innovation Key Laboratory of Sichuan Province, Sichuan Agricultural University, Chengdu 611130, Sichuan, China. ${ }^{2}$ Institute of Ecology, Key Laboratory of Southwest China Wildlife Resources Conservation (Ministry of Education), China West Normal University, Nanchong 637009, Sichuan, China.

Received: 4 March 2019 Accepted: 27 January 2020

Published online: 04 February 2020

\section{References}

1. Shahjahan M, Liu RR, Zhao GP, Zhang JJ, Zheng MQ, Li QH, Wen J. Polymorphisms in GJA1 and their association with growth traits in chicken. Genet Mol Res. 2015;14(4):18839-50.

2. Leng L, Li H. Relationship between combined genotypes of UCP gene and Growth traits in chickens. J Northeast Agric Univ. 2012;19(2):47-53.

3. Wolc A, Jankowski T, Arango J, Settar P, Fulton JE, O'Sullivan NP, Dekkers JCM. Investigating the genetic determination of clutch traits in laying hens. Poultry Sci. 2018.

4. Tina F, Spela M, Dusan T, Antonija H, Milena K. Thirty-four generations of divergent selection for 8-week body weight in chickens. Poult Sci. 2014; 93(1):16-23.

5. Sadeghi M, Niknafs S, Shahrbabak HM, Fatemi SA. Two SNP in STAT5B gene and their association with breeding value of growth and egg production traits in Mazandaran indigenous chicken. Livest Sci. 2012;147(1-3):198-202.

6. Jacobsson L, Park HB, Wahlberg P, Fredriksson R, Perez-Enciso M, Siegel PB, Andersson L. Many QTLs with minor additive effects are associated with a large difference in growth between two selection lines in chickens. Genet Res. 2005;86(2):115-25.

7. Wahlberg P, Carlborg Ö, Foglio M, Tordoir X, Syvänen AC, Lathrop M, Gut IG, Siegel PB, Andersson L. Genetic analysis of an F 2 intercross between two chicken lines divergently selected for body-weight. BMC Genomics. 2009:10(1):1-13.

8. Abasht B, Sandford E, Arango J, Settar P, Fulton JE, O'Sullivan NP, Hassen A, Habier D, Fernando RL, Dekkers JC, et al. Extent and consistency of linkage disequilibrium and identification of DNA markers for production and egg quality traits in commercial layer chicken populations. BMC Genomics. 2009; 10(Suppl 2):S2. 
9. Uemoto Y, Suzuki C, Sato S, Sato S, Ohtake T, Sasaki O, Takahashi H, Kobayashi E. Polymorphism of the ovocalyxin-32 gene and its association with egg production traits in the chicken. Poult Sci. 2009;88(12):2512-7.

10. Guan RF, Fei L, Chen XQ, Ma JQ, Jiang $H$, Xiao CG. Meat quality traits of four Chinese indigenous chicken breeds and one commercial broiler stock. J Zhejiang Univ Sci B. 2013;14(10):896-902.

11. Sheng Z, Pettersson ME, Hu X, Luo C, Hao Q, Shu D, Xia S, Carlborg Ö, Ning $L$. Genetic dissection of growth traits in a Chinese indigenous $\times$ commercial broiler chicken cross. BMC Genomics. 2013;14(1):151.

12. Li XY, Qu LJ, Yao JF, Yang N. Skewed allele frequencies of an $m x$ gene mutation with potential resistance to avian influenza virus in different chicken populations. Poult Sci. 2006;85(7):1327-9.

13. Molee A, Kongroi K, Kuadsantia P, Poompramun C, Likitdecharote B. Association between single nucleotide polymorphisms of the major histocompatibility complex class II gene and Newcastle disease virus titre and body weight in Leung hang Khao chickens. Asian Australas J Anim Sci. 2016;29(1):29-35.

14. Su YJ, Shu JT, Zhang M, Zhang XY, Shan YJ, Li GH, Yin JM, Song WT, Li HF, Zhao GP. Association of chicken growth hormone polymorphisms with egg production. Genet Mol Res. 2014;13(3):4893-903.

15. El-Sabrout K, Aggag S. Association of Single Nucleotide Polymorphism in Melanocortin receptor gene with egg production traits in Lohmann Brown chickens. Kafkas Universitesi Veteriner Fakultesi Dergisi. 2018;24:145-8.

16. Awad A, Eltarabany MS. Association of single nucleotide polymorphism in bone morphogenetic protein receptor 1B (BMPR-1B) gene with growth traits in chicken. Kafkas Üniversitesi Veteriner FakÜltesi Dergisi. 2015;21(6):813-8.

17. Abdalhag MA, Zhang T, Fan QC, Zhang XQ, Zhang GX, Wang JY, Wei Y, Wang YJ. Single nucleotide polymorphisms associated with growth traits in Jinghai yellow chickens. Genet Mol Res. 2015;14(4):16169-77.

18. Chen B, Xu J, He X, Xu H, Li G, Du H, Nie Q, Zhang X. A genome-wide mRNA screen and functional analysis reveal FOXO3 as a candidate gene for chicken growth. PLoS One. 2015;10(9):e0137087.

19. Fan QC, Wu PF, Dai GJ, Zhang GX, Zhang T, Xue Q, Shi HQ, Wang JY. Identification of 19 loci for reproductive traits in a local Chinese chicken by genome-wide study. Genet Mol Res. 2017;16(1):1-8.

20. Han C, An G, Du X. Three novel single nucleotide polymorphisms of the 3hydroxy-3-methylglutaryl coenzyme a reductase gene associated with eggproduction in chicken. Folia Biol. 2014;62(3):203-9.

21. Han H, Lei Q, Zhou Y, Gao J, Liu W, Li F, Zhang Q, Lu Y, Cao D. Association between BMP15 gene polymorphism and reproduction traits and its tissues expression characteristics in chicken. PLoS One. 2015;10(11):e0143298.

22. Han RL, Lan XY, Zhang LZ, Ren G, Jing YJ, Li MJ, Zhang B, Zhao M, Guo YK, Kang XT. A novel single-nucleotide polymorphism of the visfatin gene and its associations with performance traits in the chicken. J Appl Genet. 2010; 51(1):59-65.

23. Lei MM, Nie QH, Peng X, Zhang DX, Zhang XQ. Single nucleotide polymorphisms of the chicken insulin-like factor binding protein 2 gene associated with chicken growth and carcass traits. Poult Sci. 2005;84(8):1191-8.

24. Li CY, Li H. Association of MC4R gene polymorphisms with growth and body composition traits in chicken. Asian Aust J An Sci. 2006;19(6):763-8.

25. Nie Q, Fang M, Xie L, Zhou M, Liang Z, Luo Z, Wang G, Bi W, Liang C, Zhang W. The PIT1 gene polymorphisms were associated with chicken growth traits. BMC Genet. 2008;9(1):1-5.

26. Nie QH, Fang MX, Xie L, Shen X, Liu J, Luo ZP, Shi JJ, Zhang XQ. Associations of ATGL gene polymorphisms with chicken growth and fat traits. J Appl Genet. 2010;51(2):185-91.

27. Thobela LT, Qin N, Liu D, Niu X, Zhu H, Xu R. The association between novel polymorphisms of gremlin genes and egg-laying performance traits in Chinese village dagu hens. Ann Anim Sci. 2018;18(2):361-73.

28. Wang Y, Xu HY, Gilbert ER, Peng X, Zhao XL, Liu YP, Zhu Q. Detection of SNPs in the TBC1D1 gene and their association with carcass traits in chicken. Gene. 2014;547(2):288-94.

29. Wang Y, Zhu Q, Zhao XL, Yao YG, Liu YP. Association of FATP1 gene polymorphisms with chicken carcass traits in Chinese meat-type quality chicken populations. Mol Biol Rep. 2010;37(8):3683-90.

30. Wolc A, Arango J, Settar P, Fulton JE, O'Sullivan NP, Preisinger R, Habier D, Fernando R, Garrick DJ, Hill WG. Genome-wide association analysis and genetic architecture of egg weight and egg uniformity in layer chickens. Anim Genet. 2012;43(s1):87-96.

31. Xiaorong G, Chungang F, Li M, Chi S, Yanqiang W, Yang D, Huifang L, Kuanwei C, Shaohui Y, Changrong G. Genome-wide association study of body weight in chicken F2 resource population. PLoS One. 2011;6(7):e21872.
32. Yuan J, Sun C, Dou T, Yi G, Qu L, Qu L, Wang K, Yang N. Identification of promising mutants associated with egg production traits revealed by genome-wide association study. PLoS One. 2015;10(10):e0140615.

33. Zhang ZR, Liu YP, Yao YG, Jiang XS, Du HR, Zhu Q. Identification and association of the single nucleotide polymorphisms in calpain3 (CAPN3) gene with carcass traits in chickens. BMC Genet. 2009;10(1):1-7.

34. Ellis JA, Ong B. The MassARRAY ${ }^{\circledast}$ system for targeted SNP genotyping. Methods Mol Biol. 2017;1492:77-94.

35. Ibarrola-Villava M, Fleitas T, Llorca-Cardeñosa MJ, Mongort C, Alonso E, Navarro S, Burgues O, Vivancos A, Cejalvo JM, Perez-Fidalgo JA. Determination of somatic oncogenic mutations linked to target-based therapies using MassARRAY technology. Oncotarget. 2016;7(16):22543-55.

36. Soller M, Weigend S, Romanov MN, Dekkers JCM, Lamont SJ. Strategies to assess structural variation in the chicken genome and its associations with biodiversity and biological performance. Poult Sci. 2006:85(12):2061-78.

37. Carlborg O, Kerje S, Schutz K, Jacobsson L, Jensen P, Andersson L. A global search reveals epistatic interaction between QTL for early growth in the chicken. Genome Res. 2003;13(3):413-21.

38. Mwacharo JM, Nomura K, Hanada H, Jianlin H, Hanotte O, Amano T. Genetic relationships among Kenyan and other east African indigenous chickens. Anim Genet. 2010;38(5):485-90.

39. Mtileni BJ, Muchadeyi FC, Maiwashe A, Groeneveld E, Groeneveld LF, Dzama K, Weigend S. Genetic diversity and conservation of south African indigenous chicken populations. J Anim Breed Genet. 2011;128(3):209-18.

40. Falconer DS, Mackay TFC. Introduction to quantitative genetics. Am J Hum Genet. 1990:46(6):1231

41. Wragg D, Mwacharo JM, Alcalde JA, Hocking PM, Hanotte O. Analysis of genome-wide structure, diversity and fine mapping of Mendelian traits in traditional and village chickens. Heredity. 2012;109(1):6-18.

42. Desta TT, Dessie T, Taye T, Dana N, Ayalew W, Hanotte O. Current state of knowledge on phenotypic characteristics of indigenous chickens in the tropics. Worlds Poultry Sci J. 2011;67(3):507-16.

43. Yu LT, Xiao YP, Li JJ, Ran JS, Yin LQ, Liu YP, Zhang L. Molecular characterization of a novel ovodefensin gene in chickens. Gene. 2018;678:233-40.

44. Zhang L, Chen D, Yu L, Wei Y, Li J, Zhou C. Genome-wide analysis of the ovodefensin gene family: monophyletic origin, independent gene duplication and presence of different selection patterns. Infect Genet Evol. 2019;68(2019):265-72.

45. Zhang L, Jie H, Xiao Y, Zhou C, Lyu W, Bai W. Genomic identification and expression analysis of the cathelicidin gene family of the Forest musk deer. Animals. 2019;9:481.

46. Porras-Hurtado L, Ruiz Y, Santos C, Phillips C, Carracedo A, Lareu MV. An overview of STRUCTURE: applications, parameter settings, and supporting software. Front Genet. 2013:4(98):1-13.

47. Jakobsson M, Rosenberg N. CLUMPP: a cluster matching and permutation program for dealing with label switching and multimodality in analysis of population structure. Bioinformatics. 2007;23(14):1801-6.

48. Evanno G, Regnaut S, Goudet J. Detecting the number of clusters of individuals using the software STRUCTURE: a simulation study. Mol ECol. 2010;14(8):2611-20.

49. Rosenberg NA. DISTRUCT: a program for the graphical display of population structure. Mol Ecol Resour. 2010;4(1):137-8.

\section{Publisher's Note}

Springer Nature remains neutral with regard to jurisdictional claims in published maps and institutional affiliations.

Ready to submit your research? Choose BMC and benefit from:

- fast, convenient online submission

- thorough peer review by experienced researchers in your field

- rapid publication on acceptance

- support for research data, including large and complex data types

- gold Open Access which fosters wider collaboration and increased citations

- maximum visibility for your research: over $100 \mathrm{M}$ website views per year

At BMC, research is always in progress.

Learn more biomedcentral.com/submission 